\title{
JNPH
}

Volume 7 No. 1 (April 2019)

(C) The Author(s) 2019

\section{HUBUNGAN OBESITAS DAN KEBIASAAN OLAH RAGA DENGAN KAPASITAS PARU MAHASISWA POLTEKKES KEMENKES BENGKULU TAHUN 2017}

\author{
RELATIONSHIP OF OBESITY AND SPORTS HABITS TO STUDENTS 'LUNG \\ CAPACITY OF POLTEKKES KEMENKES BENGKULU YEAR 2017
}

\author{
HERU LAKSONO ${ }^{1}$, NERRY YUNITA ${ }^{2}$, WIDIA LESTARI ${ }^{3}$, DAISY NOVIRA ${ }^{4}$ \\ POLITEKNIK KESEHATAN KEMENTERIAN KESEHATAN BENGKULU ${ }^{1,3,4}$ \\ PUSKESMAS SAWAH LEBAR KOTA BENGKULU ${ }^{2}$ \\ Email: heru.laksono0807@gmail.com
}

\begin{abstract}
ABSTRAK
Oksigen dibutuhkan manusia agar proses metabolisme sel berjalan baik, dimana paru-paru berperan dalam proses pengambilan oksigen dari atmosfer menuju tubuh. Penurunan fungsi paru memberikan buruk diantaranya: terganggunya fungsi metabolisme, penurunan stamina dan daya tahan tubuh, risiko serangan jantung dan stroke meningkat, fatigue, penurunan fokus umum, konsentrasi dan memori, serta meningkatkan respon peradangan (Davis, 2013). Alat utama dalam test fungsi paru adalah spirometer untuk mengukur perubahan volume paru dengan pertukaran gas yang ada diatmosfer (Ronal, B et al, 2015). Jenis penelitian ini deskriptif analitik dengan rancangan cross sectional. Penelitian dilakukan pada 109 orang mahasiswa Jurusan Keperawatan Poltekkes Kemenkes Bengkulu. Data didapat dari pengisian kuesioner, pengukuran berat badan, tinggi badan dan kapasitas paru. Analisis data dilaksanakan secara kuantitatif yaitu univariat dan bivariat. Berdasarkan hasil penelitian didapatkan bahwa sebagian besar (87.2\%) responden memiliki kapasitas paru kurang, sebagian kecil (11.9\%) responden obesitas, lebih dari separuh (65.1) responden tidak punya kebiasaan berolahraga. Tidak ada hubungan antara obesitas dan kapasitas paru $(p=0.140)$. Ada hubungan bermakna antara kebiasaan olahraga dan kapasitas paru $(p=0.005)$. Berdasarkan hasil penelitian ini masa akan datang disarankan untuk melihat pengaruh beberapa faktor lain terhadap penurunan kapasitas paru.
\end{abstract}

Kata Kunci: Kapasitas Paru, Obesitas, Olahraga

\begin{abstract}
Oxygen is needed by humans so that the cell metabolic process runs well, where the lungs play a role in the process of taking oxygen from the atmosphere to the body. Decreasing pulmonary function provides such as: disruption of metabolic functions, decreased stamina and endurance, increased risk of heart attack and stroke, fatigue, decreased general focus, concentration and memory, and increased inflammatory response (Davis, 2013). The main tool in pulmonary function tests is a spirometer to measure changes in lung volume with gas exchange that is diatmosfer (Ronal, B et al, 2015). This type of research is descriptive analytic with cross sectional design. The study was conducted on 109 students of the Nursing Department of Health Polytechnic of the Ministry of Health in Bengkulu. Data obtained from filling out
\end{abstract}


questionnaires measuring weight, height and lung capacity. Data analysis was carried out quantitatively namely univariate and bivariate. Based on the results of the study it was found that most $(87.2 \%)$ respondents had less lung capacity, a small proportion (11.9\%) of respondents were obese, more than half (65.1) of respondents did not have the habit of exercising. There was no relationship between obesity and lung capacity $(p=0.140)$. There was a significant relationship between exercise habits and lung capacity $(\mathrm{p}=0.005)$. Based on the results of this study in the future it is recommended to look at the influence of several other factors on decreasing lung capacity.

\section{Keywords: Lung Capacity, Obesity, Sports}

\section{PENDAHULUAN}

Oksigen dibutuhkan oleh manusia agar proses metabolisme sel dapat berjalan dengan baik. Proses pengambilan oksigen dari atmosfer menuju ke tubuh dilakukan oleh sistem pernapasan terutama paru-paru. Semakin baik fungsi paru maka jumlah oksigen yang dapat diambil oleh paru-paru selama satu kali inspirasi lebih banyak, tubuh pun menggunakan energi lebih sedikit dan mengurangi beban kerja organ tubuh lain terutama jantung. Penurunan fungsi paru memberikan beberapa dampak buruk diantaranya: terganggunya fungsi metabolisme, stamina dan daya tahan tubuh menurun, meningkatkan risiko serangan jantung dan stroke, fatigue, penurunan fokus umum, konsentrasi dan memori, dan meningkatkan respon peradangan (Davis, 2013).

Banyak penelitian yang menghubungkan antara penurunan kapasitas paru dengan kejadian beberapa penyakit. Penelitian fungsi paru di Honolulu yang melibatkan 5.925 reponden diketahui bahwa terdapat hubungan yang significan $(\mathrm{p}=0,0004)$ antara penurunan fungsi paru dengan kejadian penyakit jantung koroner (Marcus. et al, 1989). Menurut American Lung Association manusia dewasa biasanya melakukan inspirasi 15 sampai 20 kali dalam semenit atau sekitar 20.000 kali sehari. Pernapasan adalah proses yang sangat kompleks dan melibatkan berbagai organ. Studi Framingham yang diikuti 5.200 orang selama tiga dekade menunjukkan bahwa volume paru merupakan salah satu hal yang sangat berpengaruh terhadap kesehatan dan

peningkatan harapan hidup (Kannel, et al, 1983). Uji fungsi paru adalah melakukan tes agar diketahui fungsi paru dalam kondisi normal atau abnormal.

Penurunan fungsi paru yang terjadi secara mendadak dapat menimbulkan keadaan yang disebut gagal napas dan dapat mendatangan kematian kepada penderita (Blondshine, 2000) Sejumlah gangguan dapat menyebabkan perubahan yang berbahaya di paru-paru dan saluran pernafasan. Efek yang paling penting adalah pada saluran napas dan elastisitas paru-paru. Alat utama yang digunakan dalam test fungsi paru adalah spirometer yang dirancang untuk mengukur perubahan volume dan hanya dapat mengukur volume paru dengan pertukaran gas yang ada diatmosfer (Ronal, et al, 2015). Pengujian spirometri adalah penting dalam mendeteksi beberapa kelainan yang berhubungan dengan gangguan pernapasan. Kapasitas vital paru adalah jumlah maksimum udara yang dapat dikeluarkan seseorang dari paru setelah terlebih dahulu penghisapan secara maksimum (Guyton \& Hall, 2008). Banyak faktor yang dapat mempengaruhi fungsi paru diantaranya: jenis kelamin, berat badan (obesitas, distribusi lemak, massa lemak bebas), merokok (aktif, pasif), ras, aktifitas fisik, faktor genetik, polusi udara (paparan dan / atau lingkungan), penyakit pernapasan, hipertensi, diabetes mellitus, gangguan otot, gangguan hormonal, dll (Barud, 2006).

Berdasarkan latar belakang tersebut peneliti tertarik melakukan penelitian tentang "Hubungan Kebiasaan Olah Raga dan Obesitas dengan kapasitas vital paru mahasiswa tingkat II Poltekkes Kemenkes 


\section{METODE PENELITIAN}

Jenis penelitian ini adalah analitik dengan rancangan penelitian cross sectional. Penelitian ini bertujuan untuk mengetahui analisis hubungan obesitas dan kebiasaan olahraga dengan kapasitas paru mahasiswa Jurusan Keperawatan Poltekkes Kemenkes Bengkulu (Nursalam, 2008). Penelitian dilakukan dari bulan Februari hingga Nopember 2017 di Laboratorium Terpadu Poltekkes Kemenkes Bengkulu.

Sampel pada penelitian ini adalah Mahasiswa Tingkat II Jurusan Keperawatan Poltekkes Kemenkes Bengkulu Sejumlah 109 mahasiswa. Selanjutnya mahasiswa dikumpulkan dalam rangka memperoleh penjelasan mengenai jalannya penelitian yang dilanjutkan dengan mengisi persetujuan menjadi responden. Pengambilan data indeks massa tubuh dan kapasitas paru dilakukan sesuai dengan waktu yang telah disepakati. Pada pertemuan ini juga diberitahukan kepada responden agar 24 jam sebelum pengukuran dilakukan tidak boleh mengkonsumsi obat bronkodilator. Kapasitas paru diukur dengan menggunakan alat Spirometri merek BTL-08 yang dirancang untuk mengukur perubahan volume dan hanya dapat mengukur volume paru dengan pertukaran gas yang ada diatmosfer. Cara penggunaannya adalah bernapas dengan maksimal kemudian tempelkan mulut pada mouthpiece spirometer kemudian dihembuskan sekuat mungkin sampai udara habis. Tutup hidung dengan penjepit untuk memastikan tidak ada udara yang keluar dari hidung. Pengukuran tersebut dilakukan 3 kali untuk memastikan pembacaan dan keakuratan hasil. (Ronald et al 2015). Sebelum mengambil hasil pengukuran, mahasiswa diberi kesempatan untuk belajar bernapas sesuai dengan prosedur pengukuran spirometri tanpa alat, lalu selanjutnya menggunakan spirometry hingga responden dapat melakukannya sesuai dengan prosedur.

\section{Analisis Univariat}

Tabel 1 Distribusi Responden Menurut Obesitas dan Kebiasaan Olahraga

\begin{tabular}{ccc}
\hline Variabel & Jumlah & Persentase \\
\hline Kapasitas Paru & & \\
\hline Kurang Baik & 95 & 87.2 \\
\hline Baik & 14 & 12.8 \\
\hline Obesitas & & \\
\hline Obesitas & 13 & 11.9 \\
\hline Tidak Obesitas & 96 & 88.1 \\
\hline Kebiasaan Olah Raga & & \\
\hline Tidak Aktif & 71 & 65.1 \\
Aktif & 38 & 34.9 \\
\hline
\end{tabular}

Pengukuran kapasitas paru dilakukan dengan menggunakan BTL 08-spirometri. Kapasitas paru dikatakan baik jika memiliki hasil diatas 3.381 L bagi laki-laki dan $2.657 \mathrm{~L}$ bagi perempuan. Kapasitas paru dikatakan kurang bila memiliki nilai kurang atau sama dengan 3.381 bagi laki-laki dan kurang sama dengan 2.657 L bagi perempuan.

\section{Analisis Bivariat}

a. Hubungan Obesitas dengan Kapasitas Paru

Tabel 2 Hubungan Obesitas dengan dengan Kapasitas Paru

\begin{tabular}{|c|c|c|c|c|c|}
\hline \multirow[t]{2}{*}{ Obesitas } & \multicolumn{2}{|c|}{ Kapasitas Paru } & \multirow[t]{2}{*}{ Total } & \multirow{2}{*}{$\begin{array}{c}\mathbf{P} \\
\text { value }\end{array}$} & \multirow{2}{*}{$\begin{array}{c}\text { OR } \\
(95 \% \\
\text { CI) } \\
\end{array}$} \\
\hline & Kurang & Baik & & & \\
\hline Obesitas & $\begin{array}{c}13 \\
(100 \%)\end{array}$ & $0(0 \%)$ & 13 & 0,140 & $\begin{array}{r}1.171 \\
(1.078\end{array}$ \\
\hline $\begin{array}{c}\text { Tidak } \\
\text { Obesitas }\end{array}$ & $\begin{array}{c}82 \\
(85.4 \%)\end{array}$ & $\begin{array}{c}14 \\
(14.58 \%)\end{array}$ & 96 & & $\begin{array}{c}- \\
1.272)\end{array}$ \\
\hline Total & $\begin{array}{c}95 \\
(95 \%) \\
\end{array}$ & $14(14 \%)$ & 109 & & \\
\hline
\end{tabular}

Berdasarkan tabel silang dapat diketahui bahwa obesitas memiliki kapasitas paru kurang yaitu sebesar 100\%. Hasil uji fisher exact diperoleh bahwa tidak ada hubungan yang signifikan antara obesitas dengan kapasitas paru $(p=0,140)$. 
b. Hubungan Kebiasaan Olah Raga dengan Kapasitas Paru

Tabel 3 Hubungan Kebiasaan Olahraga dengan Kapasitas Paru

\begin{tabular}{|c|c|c|c|c|c|}
\hline \multirow{2}{*}{$\begin{array}{l}\text { Aktifitas } \\
\text { Fisik } \\
\text { Olahraga }\end{array}$} & \multicolumn{2}{|c|}{$\begin{array}{c}\text { Kapasitas } \\
\text { Paru } \\
\end{array}$} & \multirow[t]{2}{*}{ Total } & \multirow[t]{2}{*}{$\begin{array}{c}\mathbf{P} \\
\text { value }\end{array}$} & \multirow{2}{*}{$\begin{array}{c}\text { OR } \\
(95 \% \\
\text { CI) }\end{array}$} \\
\hline & Kurang & Baik & & & \\
\hline \multicolumn{3}{|c|}{$(94.3 \%)(5.7 \%)$} & 70 & 0,005 & $\begin{array}{r}5.690 \\
(1.648\end{array}$ \\
\hline Aktif & $\begin{array}{c}29 \\
(74.4 \%)\end{array}$ & $\begin{array}{c}10 \\
(25.6 \% \\
)\end{array}$ & 39 & & $\begin{array}{c}- \\
19.64 \\
2)\end{array}$ \\
\hline Total & $\begin{array}{c}95 \\
(95 \%)\end{array}$ & $\begin{array}{c}14 \\
(14 \%)\end{array}$ & 109 & & \\
\hline
\end{tabular}

Kebiasaan olahraga diperkirakan berkaitan dengan kapasitas paru, hasil penelitian didapatkan bahwa dari 70 orang yang tidak aktif memiliki kapasitas paru kurang 94.3\%. Sedangkan dari 39 orang yang memiliki kebiasaan olahraga memiliki kapasitas paru kurang sebesar $74.4 \%$.

Hasil analisis bivariat dapat disimpulkan bahwa ada hubungan yang signifikan antara kebiasaan olahraga dengan kapasitas paru $(p=0.005)$, adapun nilai OR yang didapatkan adalah 5.690 (1.648-19.642) yang artinya bahwa responden yang memiliki kebiasaan olahraga aktif berpeluang memiliki kapasitas paru baik sebesar 6 kali dibandingkan dengan responden tidak memiliki kebiasaan olahraga.

\section{PEMBAHASAN}

Hasil penelitian menunjukkan bahwa tidak ada hubungan yang signifikan antara obesitas dengan kapasitas paru $(p=0.140)$. Hasil penelitian ini sesuai dengan penelitian Jayachandran (2015) dimana pada penelitian ini tidak terdapat perbedaan yang signifikan antara obesitas dengan kapasitas paru, penelitian ini dilakukan pada 50 orang responden laki-laki berusia antara 20-26 tahun. Namun hasil penelitian ini tidak sesuai dengan penelitian Fayed, et al (2014) yang mendapatkan hasil bahwa ada hubungan signifikan $(p$ value $=0.000)$ antara kapasitas paksa paru dengan obesitas dengan sampel sebanyak 359 orang wanita usia 18-44 tahun.

Pada penelitian ini walaupun tidak ada hubungan yang signifikan, hasil pengukuran menunjukkan bahwa dari 13 orang yang obesitas diketahui bahwa $100 \%$ memiliki kapasitas paru kurang. Hal ini sesuai dengan pernyataan Bai et al (1998) bahawa penderita obesitas memiliki resiko lebih besar terhadap keluhan gangguan pernapasan terutama mudah sesak napas ketika berolahraga, walaupun tidak memiliki penyakit pernapasan. Efek ini mencerminkan pergeseran keseimbangan tekanan inflasi dan deflasi pada paru-paru karena beban massa jaringan adiposa di sekitar tulang rusuk dan perut di rongga visceral (Sharp, et al, 1964). Obesitas mempengaruhi kapasitas paru dengan menciptakan perubahan pada gerakan mekanik pernapasan, penurunan kekuatan dan ketahan otot pernapasan, penurunan pertukaran gas paru, control pernapasan menurun, keterbatasan fungsi pernapasan ( Parameswaran, et al, 2006). Pada individu dengan obesitas terjadi perubahan mekanika respirasi atau kemampuan regangan paru.

Penurunan terjadi secara keseluruhan hampir pada semua organ pernapasan terutama kemampuan regangan paru, dinding thorax, dan system pernafasan secara keseluruhan. Penurunan regangan ini disebabkan oleh bertambahnya volume darah pulmoner dan kolapsnya saluran napas terminal. Kelebihan berat badan memberikan beban tambahan pada thorax dan abdomen dengan akibat peregangan yang berlebihan pada dinding thorax. Selain itu, otot-otot pernapasan harus bekerja lebih keras untuk menghasilkan tekanan negatif yang lebih tinggi pada rongga pleura untuk memungkinkan aliran udara masuk saat inspirasi. Peningkatan tahanan pulmonal kemungkinan besar berkaitan dengan peningkatan tahanan pada saluran napas kecil (bukan saluran napas besar) karena hasil pemeriksaan menunjukkan adanya penurunan volume paru. Tahanan paru makin meningkat bila penderita berbaring terlentang karena beban masa yang ditimbulkan oleh lemak di 
daerah supra-Iaring pada saluran napas, dan meningkatnya aliran darah pulmoner, yang pada akhirnya mengakibatkan saluran napas makin menyempit. Pada posisi terlentang juga terjadi penurunan kapasitas residual fungsional (functional recidual capasity (FRC)) yang akan menambah tahanan saluran napas. Penambahan jaringan lemak tambahan pada dinding dada dan rongga abdomen dapat menghasilkan penurunan volum paru dan penggunaan otot pernapasan tambahan karena adanya penurunan gerakan diafragma, penurunan compliance paru dan peningkatan recoil dada (Canoy.et al, 2004).

Hasil penelitian ini sejalan dengan Weiss (1991) bahwa dari 813 pasien dengan skoliosis idiopatik yang dirawat diberikan aktifitas berolahraga diketahui terdapat peningkatan kapasitas vital paru sebesar 501 ml. Pada penelitian Hutzler, et al (1998) 46 responden yang diberikan program olahraga berenang 2 kali seminggu dan atletik 1 kali seminggu selama 6 bulan diketahui terjadi peningkatan kapasitas paru sebesar $65 \%$ dari pengukuran awal. Penelitian Hojati et al (2001) terhadap 40 siswa perempuan yang tidak berolahraga, kemudian diberikan intervensi 36 sesi latihan aerobic selama 45 menit 1 sesi. Jayachandran (2015) melakukan penelitian dengan membandingkan kapasitas paru-paru dan indeks massa tubuh antara siswa pendidikan jasmani dan siswa pendidikan non-fisik, diketahui bahwa ada perbedaan yang signifikan pada kapasitas paru antara siswa pendidikan jasmani dan siswa pendidikan non-fisik.

Sistem pernapasan dan aliran darah keseluruh tubuh bergantung pada kondisi paru-paru. Kegiatan olahraga yang rutin dapat melatih otot pernapasan dan paru. Olah raga rutin dapat meningkatkan respon fisiologis tubuh, fungsi dan mekanisme kerja organ tubuh akan selalu bereaksi untuk mencapai kondisi homeostasis (kecenderungan untuk mempertahankan lingkungan yang stabil bagi selnya.

\section{British Lung Foundation (2001)} menyatakan bahwa ketika berolahraga, otototot didalam tubuh terutama otot skeletal dan otot jantung mengirimkan pesan melalui neuron aferen menuju otak bahwa tubuh membutuhkan oksigen daam jumlah besar untuk proses metabolisme yang menghasilkan ATP (Adenosine Tri Posfat). Otak akan mengirimkan sinyal menuju otot pernapasan agar berkontraksi lebih maksimal sehingga oksigen yang masuk menuju paru lebih banyak. Olahraga akan meningkatkan maximal muscular power yang meliputi peningkatan kekuatan otot dan kecepatan kontraksi otot. Peningkatan kekuatan kontraksi otot karena penambahan luas penampang otot dan peningkatan saraf yang aktif diotot. Peningkatan kecepatan kontraksi otot karena penambahan rekruitmen motor unit dan peningkatan pengeluaran impuls, kecepatan hantaran impuls dan perpindahan impuls pada sinapsis. Khusus adaptasi pada system resprasi dimana frekwensi pernapasan lebih rendah dengan daya difusi yang lebih tinggi (efisiensi pernapasan) dan kenaikan volume paru dan kapasitas paru. Kenaikan volume paru dan kapasitas paru dikaitkan dengan mitokondria sel yang meningkat jumlahnya sebesar $60 \%$, glikogen otot meningkat 2-5 kali, potensi oksidatif otot-otot meningkat sekitar 100\% sehingga VO2 mak meningkat sebanyak 13\%. Menurut Miyauci et al (2003) olah raga juga menyebabkan peningkatan spesifik pada jumlah nitrat oksida (NO) jaringan paru-paru pada tikus yang diberikan perlakuan berupa olahraga berlari di treadmill selama 45 menit. Nitrat oksida (NO) diproduksi di endotel vaskular dan merupakan zat vasodilator kuat yang berperan dalam regulasi vaskular local. Cheng et al (2003) melakukan studi cross sectional terhadap 24.536 orang sehat berusia antara 25-55 tahun ditemukan hasil bahwa responden yang tetap aktif memiliki volume ekspirasi paksa yang lebih tinggi dalam satu detik (FEV1) dan kapasitas vital paksa (FVC) lebih tinggi dibandingkan kelompok lainnya.

\section{KESIMPULAN}

Tidak ada hubungan yang bermakna antara obesitas dan kapasitas paru $(p=0.140)$. 
Ada hubungan yang bermakna antara kebiasaan olahraga dan kapasitas paru $(p=0.005)$.

\section{SARAN}

Kepada peneliti selanjutnya diharapkan agar berupaya lebih mengembangkan dan memperdalam bahasan tentang hubungan obesitas dan kebiasaan olah raga dengan kapasitas paru dengan menggunakan desain penelitian yang berbeda.

\section{DAFTAR PUSTAKA}

Andersen JH. 2005. Musculoskeletal Disorders of The Neck and Shoulders in Female Sewing Machine Operators: Prevalence, Incidence, and Prognosis. Occup Environ Med.

Borg, Stein J dan Simons DG. 2002. Focused Review: Myofascial Pain. Arch Phys Med Rehabil.

Budiarto, E. 2002. Biostatika untuk Kedokteran dan Kesehatan Masyarakat. Jakarta: EGC.

Cailliet R. 2005. Neck and arm pain Edisi ke5. Philadelphia: F.A. Davis Company.

Chaitow, Leon. 2006. Muscle Energy Techniques. Second Edition. Philadelphia: Churchill Livingstone.

Daniels JM, Ishmael T dan Wesley RM. 2003. Managing Myofascial Pain Syndrome. Phys Sport med.

David, Simons dan Pamela G. Rockwell. 2003. Trigger Points: Diagnosis and Management. Michigan: Am Fam Physician.

Dharma, Kelana Kusuma. 2011. Metodologi Penelitian Keperawatan. Jakarta: CV Trans Info Media.

Dommerholt J. Bron. 2006. Myofascial Trigger Point: An Evidence; The Journal of Manual and Manipulative Therapy. America : Maney Publishing.

Dommerholt, J., Bron, C., Franssen, J., 2006. Myofascial Trigger Points: An EvidenceInformed Review. The Journal of Manual and Manipulative Therapy, 14(4):203-
221.

Edwards, J. 2006. The Importance of Postural Habits in Perpetuaiting Myofascial Trigger Point; The jurnal of manual and manipulative therapy. Acupuntur med.

El Beialy, R.R. 1988. Temporomndibular joint (Order and Disorders). The Egyptian Printing Center; 29-46.

Elpers, K.P., and Griffith, C.A., 1999. The Use of Myofascial Release Techniques as a component of The Rehabilitation of Shoulder Dysfungsion: A Case Study. JOSPT, 29(1):A-6.

Fernandez DPC. 2005. Musculoskeletal Disorders in Mechanical Neck Pain: Myofascial Trigger Points Versus Cervical Joint Dysfunctions: A Clinical Study. Journal of Musculoskeletal Pain;13(1):27-35.

Fryer, Gary. 2011. Muscle Energy Technique: An Evidence Informed Approach. International Journal Osteopath Medicine;14(1):3-9.

Gerwin RD. 2004. Myofascial Pain and Fibromyalgia: Diagnosis and Treatment. J Back Musculoskeletal Rehabil.

Gordon, Neil F. 2005. Panduan Latihan Lengkap. Jakarta: PT. Raja Grafindo Persada.

Greenman, P.E., 1996. Principles of Manual Medicine, Second edition.Baltimore Williams and Hilkins, 146-158.

Grubb ER. 2010. Muscle Energy. University of Kentucky: 1-10.

Hakim, Hikmad. 2012. Pengaruh Latihan Isometrik dan Isotonik Terhadap Kemampuan Memanah. Competitor 4 (1):65-66.

Hou, C.R., Tsai, L.C., Cheng, K.F., Chung, K.C., and Hong, C.Z., 2002. Immediate Effects Of Various Physical Therapeutic Modalities on Cervikal Pain and Trigger Point Sensitivity. ArChi Phys Med Rehabil, 83:1406-1416.

Irwansyah. 2008. Pendidikan Jasmani Olahraga dan Kesehatan. Jakarta: Grasindo.

Kenna C, Murtagh. 2007. Back Pain and 
Spinal Manipulation. Oxford: Butterworth Heinemann.

Mense S. 2001 Muscle Pain. Baltimore: Lippincott Williams and Wilkins.

Muhajir. 2007. Pendidikan Jasmani Olahraga dan Kesehatan. Bandung: PT Ghalia Indonesia Printing.

Notoadmodjo, Soekidjo. 2010. Metodologi Penelitian Kesehatan. Jakarta: Rhineka Cipta.

Perusahaan Daerah Air Minum. 2013. Daftar Karyawan dan Pekerja Lapangan. PDAM. Bengkulu.

Potter, Patricia A. dan Anne Griffin Perry. 2005. Buku Ajar Fundamental Keperawatan: Konsep, Proses dan Praktek Volume 1. Jakarta: EGC.

Priharjo, Robert. 2008. Perawatan Nyeri Pemenuhan Aktivitas Istirahat Pasien. Jakarta: EGC.

Ramsy, S.M., 1997. Holistic Manual Therapy Techniques. J Am Osteop Ass, 24(4): 759785.

Rio, E., Kidgell, D., Purdam, C., Gaida, J., Moseley, L., Pearce, A.J., Cook, J., 2015. Isometric Exercise Induces Analgesia and Reduces Inhibition in Patelar Tendinopathy. Br J Sport Med, 49:12771283.

Sastroasmoro, Sudigdo dan Sofyan Ismael. 2011. Dasar-dasar Metodologi Penelitian Klinis Edisi 4. Jakarta: CV Sagung Seto.

Shanti, M., 2006. Manfaat Penambahan Knee Support Pada Pelaksanaan Terapi MWD, US, Latihan Isometrik Terhadap Pengurangan Nyeri Akibat Cidera Ligamen Collateral Medial Lutut Stadium Lanjut, Jurnal Fisioterapi Indonusa, 6 (1):1:-4

Sisodiya, A.S., Joshi, S.K., Singh, M., 2013. Comparative Effect of Isotonic and Isometic Exercise On The Performance of Cricket Playing Skill. International Journal of Behavioral Social and Movement Sciences, 02:277-289.

Smeltzer, Suzanne C. dan Brenda G. Bare. 2002. Buku Ajar Keperawatan Medikal Bedah Brunner dan Suddarth Edisi 8 Volume 3. Jakarta: EGC.
Tamsuri, Anas. 2007. Konsep dan Penatalaksanaan Nyeri. Jakarta: EGC.

Webster, Gill. 2001. The Physiology and Application of Muscle Energy Techniques. Spine; 45:311-316.

Wright, EF. 2000. Referred Craniofacial Pain Patterns In Patients With Temporomandibular Disorder. J Am Dent Assoc.

Zaky, L.A., El Nahass, B., El Zawahry, A.M., 2010. Myofascial Trigger Points Pressure Release Versus Exercises Therapy in The Treatment of Chronic Cervical Myofascial Pain Dysfunction Syndrome. Bull.Fac.Ph.th.Cairo Univ, 15(1):83-93. 